\title{
BUSINESS MODELS: A STRATEGIC LINK TO E-SUPPLY CHAIN MANAGEMENT
}

\author{
Said Bensbih, Mohammed HADINI \\ CIM and Industrial Engineering Laboratory (LMPGI), University Hassan II \\ Casablanca High School of Technology EST, Morocco \\ Mounire Trifess \\ LAREM, ISCAE, Casablanca, Morocco \\ Otmane Bouksour, Said Rifai \\ CIM and Industrial Engineering Laboratory (LMPGI), University Hassan II \\ Casablanca High School of Technology EST, Morocco
}

\begin{abstract}
Companies adopt strategies to assert their competitive advantage and meet the demands and expectations of their various stakeholders. It is recognized that Supply Chain Management plays an essential role in establishing this competitiveness and more particularly when information and communication technologies are implemented. We aim to explore how a business model reflects the contribution of this eSupply Chain Management to the strategic objectives of companies. Based on a literature review, we propose a conceptual framework highlighting the relationships between these three constructs.
\end{abstract}

Keywords: Supply Chain Management, Business Model, Strategy, Information and Communication Technology.

Cite this Article: Said Bensbih, Mohammed HADINI, Mounire Trifess, Otmane Bouksour, Said Rifai, Business Models: A Strategic Link to E-Supply Chain Management. International Journal of Mechanical Engineering and Technology. 11(3), 2020, pp. 1-5.

https://iaeme.com/Home/issue/IJMET?Volume=11\&Issue $=3$

\section{INTRODUCTION}

If values, vision and mission are essential elements to consider in the management of companies, it is at the level of strategy, explicit or implicit, deliberate or emerging, that the advantages vis-à-vis the competition find their source [1] [2] [3] [4]. The company to survive and prosper will seek at this level to distinguish itself from its competitors by creating value for its customers and making sure to do so through activities guaranteeing a performance allowing it to achieve its strategic objectives. 
In an era where information and communication technologies (ICTs) are emerging as key enablers for competitiveness [5], digital transformation is often necessary to maintain a viable position in the market and possibly ensure projected growth [6]. Companies then use various digital approaches and solutions to be part of this inevitable trend.

This push of digitalization, among others, has brought to light the notion of business model [7] that entrepreneurs will seek to design in order to better adopt digital in the development of their offer, the segmentation of their client portfolio and the determination of their channels of distribution. Likewise, such a business model would enable decision-makers to define their schemes for the profits to be generated while optimizing the resources to be deployed and by mobilizing the production factors to be implemented.

At this stage, the importance of calibrating a supply chain management (SCM) adapted to strategic objectives comes into play in order to perpetuate the different elements of production and to match supply to demand in an often changing and uncertain context [8]. The competitiveness of companies is increasingly dependent on this calibration and ICTs offer the possibility for this eSupply Chain Management (eSCM) to be a fundamental competitiveness enabler [9].

We aim to explore these three concepts to propose a conceptual framework capable of illustrating the links through which they interact in the decision-making process within companies.

\section{CONCEPTUAL ANALYSIS}

\subsection{Strategy: Schools and Definitions}

The concept of strategy was already present in the military field as a determining element in decision-making both in times of conflict and of peace. While some of the principles in military strategies are taken up at the economic context, the latter are aimed at objectives much more oriented towards improving business indicators such as turnover growth and profit increase [10].

In the economic world, there are different schools of strategy which can be classified between prescriptive and descriptive. For our work, we are mainly interested in one of the most commonly adopted approaches namely generic strategies as proposed by Porter [11].

A company will indeed seek to stand out by using the three possible options, which can also be combined: the product, the price and the customer segment. The decision for a given positioning could be taken via an analysis of strengths, weaknesses, opportunities and threats, SWOT [12].

Associated with this strategic positioning, a digital transformation is often initiated in a more or less accentuated manner depending on the context of the market in which the company is positioned. The degree of digitalization and investment in ICTs will depend not only on competitive needs but also on the strategic value attributed by the company to digital orientation.

\subsection{Business Model: An Emergent Concept in the Digital Era}

The impact of the internet on business has been such that several large companies that have not sufficiently perceived this wave have simply failed to maintain their competitive advantage. Some start-ups, on the other hand, have been able to ride this wave and have achieved meteoric growth [13].

To the unprecedented success of these digital companies, has often been associated an emerging concept that is the business model by attributing it originality in a positioning that 
makes best use of the Internet and ICTs [14]. The ways to create value and target customers have been completely innovated.

Having a successful business model has thus become a sine qua none condition for the sustainability of companies in several sectors. Some players in traditional sectors had to review their strategies to ensure their survival in the face of new entrants with creative and innovative business models.

If this new concept is sometimes located at the same level as the strategy [15], we consider it rather a tool declining the strategic objectives of the company and its positioning.

\section{3. eSupply Chain Management: A Competitiveness Enabler}

As well upstream of the development of the business plan of a company in creation project or during the regular planning of the resources necessary for the production of goods and services, it is crucial to proceed to the adequate design and to align the different components of the supply chain [16].

The flows of human, material and information resources must be considered to allow supply chain management to be lean or agile depending on the market context, the degree of personalization of products and services as well as the volume at the demand level [17]. Internet and more generally ICTs are adopted to have an eSCM which can contribute to consolidate the competitiveness of the company [18] [19]. It is at this stage that products are adapted to demand while optimizing costs.

\section{A CONCEPTUAL FRAMEWOK PROPOSAL}

From the developments below, we propose the conceptual framework illustrated in Figure 1 by tracing the eSCM components on the nine dimensions proposed by Osterwalder et al. [20]. In the following we proceed to the argumentation underlying this framework.

Firstly, eSCM intervenes as a key element in the feedback of customer information (purchases, satisfaction, product returns, etc.) to better guide value creation and meet market expectations. At this level, the information flow is enriched by the options offered by social networks, digital platforms and Customer Relationships Management (CRM) solutions that cross eSCM processes. This will also make it possible to refine the distribution methods and to act on the promotion levers of the offer and its adaptation to customer demand.

eSCM is also directly involved in determining the costs associated with price proposals acceptable to the market. These critical factors for the competitiveness of the company will depend on the capacity that eSCM offers to ensure the essential activities by optimizing the necessary resources according to the nature of supply and demand.

Finally, for the partner dimension, eSCM will lead to possible cooperation with companies and organizations to carry out its activities. It can be a question of subcontracting or outsourcing operations which are not part of the core business but it can also consist in the implementation of means of communication and information ensuring for example a technological or regulatory watch. 


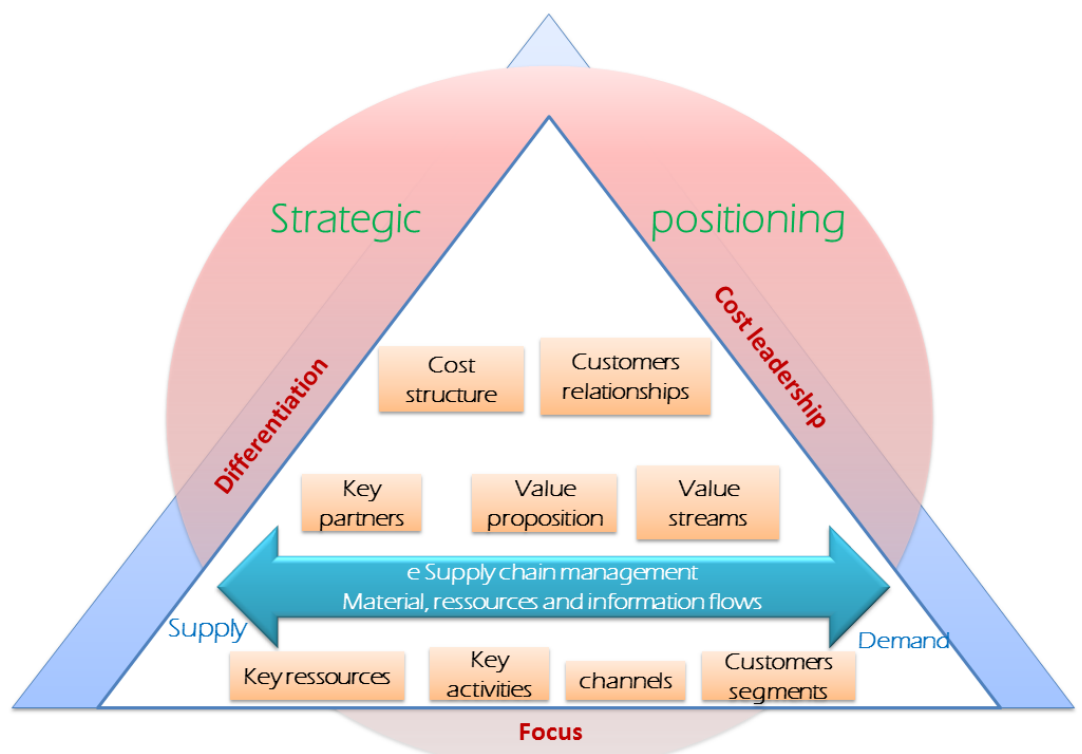

Figure 1 A Conceptual Framework for Strategy, Business model and eSCCM integration

\section{CONCLUSION AND PERSPECTIVES}

Many research works have been interested in the concepts of strategy, business model and SCM as well as the links between them. However, and to our knowledge, few publications have addressed the association of the three concepts at the same time.

The conceptual framework that we propose makes a contribution in this sense both on a theoretical and practical level by allowing decision-makers the means to consider the deployment of eSCM through the business model canvas which in turn explains the strategic positioning of companies. More work is needed on the one hand to challenge the proposed conceptual framework and on the other to explore the integration of the other dimensions of the three concepts studied.

\section{REFERENCES}

[1] Kaplan, R. S., Davenport, T. H., Robert, N. P. D. K. S., Kaplan, R. S., \& Norton, D. P. (2001). The strategy-focused organization: How balanced scorecard companies thrive in the new business environment. Harvard Business Press.

[2] Kim, W. C., \& Mauborgne, R. (2014). Blue ocean strategy, expanded edition: How to create uncontested market space and make the competition irrelevant. Harvard business review Press.

[3] Mintzberg, H., Ahlstrand, B., \& Lampel, J. (2005). Strategy Safari: a guided tour through the wilds of strategic mangament. Simon and Schuster.

[4] Porter, M. E. (1989). How competitive forces shape strategy. In Readings in strategic management (pp. 133-143). Palgrave, London.

[5] Ollo-López, A., \& Aramendía-Muneta, M. E. (2012). ICT impact on competitiveness, innovation and environment. Telematics and Informatics, 29 (2), 204-210.

[6] Matt, C., Hess, T., \& Benlian, A. (2015). Digital transformation strategies. Business \& Information Systems Engineering, 57(5), 339-343.

[7] Wirtz, B. W., Pistoia, A., Ullrich, S., \& Göttel, V. (2016). Business models: Origin, development and future research perspectives. Long range planning, 49(1), 36-54. 
[8] Wong, C., Skipworth, H., Godsell, J., \& Achimugu, N. (2012). Towards a theory of supply chain alignment enablers: a systematic literature review. Supply Chain Management: An International Journal, 17(4), 419-437.

[9] GIMÉNEZ, Cristina \& LOURENÇO, Helena R. e-SCM: internet's impact on supply chain processes. The International Journal of Logistics Management, 2008, vol. 19, no 3, p. 309-343.

[10] Ronda-Pupo, G. A., \& Guerras-Martin, L. Á. (2012). Dynamics of the evolution of the strategy concept 1962-2008: a co-word analysis. Strategic management journal, 33(2), 162-188.

[11] Porter, M. E. (1996). What is strategy? Harvard business review, 74(6), 61-78.

[12] Helms, M. M., \& Nixon, J. (2010). Exploring SWOT analysis-where are we now? Journal of strategy and management.

[13] De Massis, A., Frattini, F., \& Quillico, F. (2016). What big companies can learn from the success of the unicorns? Harvard Business Review

[14] Baden-Fuller, C., \& Haefliger, S. (2013). Business models and technological innovation. Long range planning, 46(6), 419-426.

[15] Magretta, J. (2002). Why business models matter. Retrieved from http://designblog.uniandes.edu.co/blogs/dise2102pc/files/2013/08/Why_Business_Models _Matter2.pdf on February 25th, 2020.

[16] Chi, T., Kilduff, P. P., \& Gargeya, V. B. (2009). Alignment between business environment characteristics, competitive priorities, supply chain structures, and firm business performance. International Journal of productivity and performance management.

[17] Mason-Jones, R., Naylor, B., \& Towill, D. R. (2000). Lean, agile or leagile? Matching your supply chain to the marketplace. International Journal of Production Research, 38(17), 4061-4070.

[18] Akyuz, G. A., \& Rehan, M. (2009). Requirements for forming an 'e-supply chain'. International Journal of Production Research, 47(12), 3265-3287.

[19] Dotoli, M., Fanti, M. P., Meloni, C., \& Zhou, M. (2005). Design and optimization of integrated e-supply chain for agile and environmentally conscious manufacturing. IEEE Transactions on Systems, Man, and Cybernetics-Part A: Systems and Humans, 36(1), 6275.

[20] Osterwalder, A., \& Pigneur, Y. (2010). Business model generation: a handbook for visionaries, game changers, and challengers. John Wiley \& Sons. 